\title{
Benign Myoepithelioma
}

National Cancer Institute

\section{Source}

National Cancer Institute. Benign Myoepithelioma. NCI Thesaurus. Code C7442.

A tumor with myoepithelial differentiation that lacks an infiltrative growth pattern and does not metastasize. 